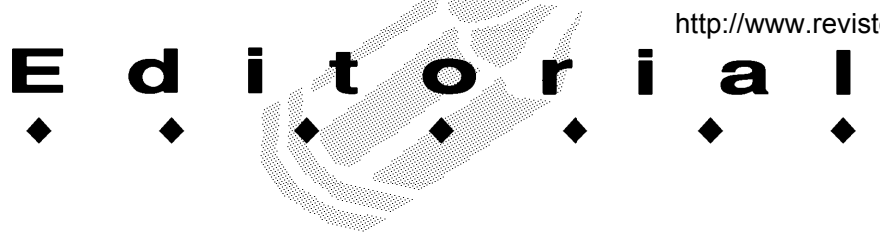

\title{
DE LA REFORMA DE L'ESPERANZA A L'ESPERANZA AGUIRRE DE LA CONTRAREFORMA
}

Les declaracions, matisacions i contradeclaracions de la ministra d'Educació i Cultura sobre la previsible reforma dels ensenyaments d'humanitats han configurat, conjuntament amb els aplaudiments dels escolans de la seva política i els xiulets d'una munió heterogènia de defensors dels valors de l'esquerra, un amaniment per a taula que ha divertit, i en alguns casos molestat, per la insistència a repetir tòpics sense fonament.

El fons del fons és que la reforma de l'esperança s'havia gestat, bàsicament, per un partit socialista encarcarat $i$ en hores baixes, on encara predominaven alguns dels valors que amb el temps anava perdent, quasi sense adonar-se'n: llibertat i responsabilitat. La reforma volia donar a entendre, sobretot, que aquests dos grans conceptes d'esquerra entraven per primera vegada en un disseny curricular, per formar ciutadans lliures i responsables, amb un professorat que calia renovar.

Aquesta ideologia pressuposava, evidentment, una altra filosofia de treball per als professionals, en la qual s'hi volia incloure la idea de decisió davant de les propostes del currículum obert, en el sentit que calia saber triar per arribar a uns objectius finals d'anàlisi i de comprensió, i no només de transmissió. Era, és i serà una aposta difícil, ja que els mestres i llicenciats sempre hem tingut el menjar a punt a través de llibres de text ja programats, ja tancats. Podíem finalment arribar a ser més lliures, basats en una responsabilitat individual i col.lectiva de centre, on les decisions les havíem de prendre amb un sentit crític, pensant.

La llibertat i la responsabilitat, però, ens l'havíem de guanyar a pols, treballant i estudiant, estudiant i treballant. No només canviant el xip ens venia la ciència infusa d'aquests valors. I això costava. Havíem d'aprofundir com enteníem la llibertat per poder aplicar-la amb escreix, havíem de prosseguir amb la responsabilitat per irradiar-la i per demostrar que podíem ensenyar i aprendre conjuntament amb els alumnes i els pares, treballant plegats en uns programes oberts, en construcció permanent.

La ministra ho ha volgut i ho vol trastocar. Vol posar més coneixements, més continguts factuals en detriment de saber fer, d'entendre, de la comprensió significativa. En història potser els sufridors alumnes sabran dades $\mathrm{i}$ fets històrics que els serviran per al que serveixen avui: per a un concurs cultural de la tele, però segurament no sabran els perquès, els veritables canvis dels fets històrics, el rol de les dones i els homes en els diversos tipus de societat.

La contrareforma del govern de l'Esperanza, moguda més per interessos que no pas per ideals -com pertoca a un govern de dreta-, torna a abocar el professor a ser dòcil, a no haver de pensar gaire, a recitar la lliçó per preguntar, a seguir la doctrina dels il.luminats, a rebolcar-nos en la mandra i en el pessimisme. I l'alumne, a l'ostracisme.

Des de la didàctica i des dels MRP ens agradaria parlar per avançar. 